Foundation has been received for research on filariasis. Instruction in tropical medicine for medical students has been increased at the Institute, and its laboratories are now available to officers of the armed services and to others who need to go to the tropics. Intensive courses for graduates are also being provided and it is expected that very soon a full year's course will be available. There is hope that new buildings will be possible soon after the War.

Dr. Mustard echoes Prof. Stunkard's words when he says that ". . . the very business of war depends upon a successful combating of tropical diseases". Not only is the health of the fighting forces concerned, but also that of local populations in the tropics who are required for getting raw materials, building airfields and general labour. Alliances, treaties and national and trade interests are more than ever taking United States Government officials, business men and others to the tropies by ship and aeroplane, and these men, ships and aeroplanes may bring back tropical diseases and their vectors. "The universities of the United States cannot remain aloof from the realities of this situation," says Dr. Mustard. Only a few United States universities, he states, will be able to offer courses in tropical medicine, the number being limited by their position and resources. A university giving such courses should be in a great city which is a great centre of rail, sea and air transit, especially transit to and from the tropics; and it should be a recognized cultural, educational and medical centre and have international prestige and an outstanding school of medicine. Columbia University in New York City, with its unique relation with the School of Tropical Medicine at Puerto Rico and with the College of Physicians and Surgeons, would certainly seem, as Dr. Mustard suggests, to be well fitted to undertake this vitally important work.

\section{Solar Research in Belgium during 1942}

A NOTE on this subject by Swings (Astrophys. $J$., $99,118 ; 1944)$ reports that the University of Liège still continues its programme of astronomical infrared spectroscopy, and that in June 1942 a new selfrecording high-dispersion spectrograph was installed in the constant-temperature basement of the solar tower. This instrument utilizes four plane echelette gratings with $15,000,3,600,2,400$ and 1,200 lines per inch respectively, the whole spectrum from $1 \mu$ to $20 \mu$ being covered with a resolving power which will separate lines $1 \mathrm{~cm} .^{-1}$ apart. A preliminary paper by Migeotte gives a general account of the results obtained from recordings of the solar spectrum in the region near $1.5 \mu$. Here absorption lines only $1.5 \mathrm{~A}$. apart can be separated, and the distinction between solar and telluric lines is relatively simple. A study of the water-vapour spectrum in this region is nearing completion, and the new instrument is now in continuous operation.

\section{Research in the Caribbean}

Prof. J. L. Simonsen, director of research of the Colonial Products Research Council, Sir Robert Robinson, Waynflete professor of chemistry in the University of Oxford, and a member of the Council, are now on a visit to the Caribbean area, where they are discussing fundamental problems of research on new uses for Colonial raw materials, with specific reference to the co-ordination of the work of the Colonial Products Research Council with that of the Caribbean Research Council.

\section{Biography of the late Lord Cadman, F.R.S.}

Mr. Ivor Evans has been entrusted with the writing of the biography of the late Lord Cadman. Readers of Nature possessing letters, etc., likely to be of interest are asked to forward them to $\mathrm{Mr}$. Evans, c/o Mr. James Cadman, Walton Hall, Eccleshall, Staffs.

\section{Night Sky in September}

Full moon occurs on Sept. 2d. 20h. 21m. U.T. and new moon on Sept. 17d. $12 \mathrm{~h} .37 \mathrm{~m}$. The following conjunctions with the moon take place: Sept. 11d. 06h., Saturn 0.7 $7^{\circ}$ N.; Sept. 16d. 01h., Mercury $5^{\circ}$ S. ; Sept. 16d. 08h., Jupiter $3^{\circ}$ S.; Sept. $19 \mathrm{~d}$. 00h., Mars $5^{\circ}$ S. ; Sept. 19d. $11 \mathrm{~h}$. , Venus $5^{\circ}$ S. In addition to the above, the following planetary conjunctions also take place: Sept. 10d. $02 \mathrm{~h}$., Venus in conjunction with Mars, Venus $0 \cdot 5^{\circ} \mathrm{N}$.; Sept. $23 \mathrm{~d}$. 16h., Mercury in conjunction with Jupiter, Mercury $0 \cdot 1^{\circ} \mathrm{N}$. Mercury is in inferior conjunction on Sept. 6, stationary on Sept. 15, and attains its greatest western elongation on Sept. 22. The times of rising of the planet at the beginning, middle and end of the month are $6 \mathrm{~h} .31 \mathrm{~m} ., 4 \mathrm{~h} .15 \mathrm{~m}$. , and $4 \mathrm{~h} .32 \mathrm{~m}$. respectively. Venus sets at $19 \mathrm{~h} .29 \mathrm{~m} ., 18 \mathrm{~h} .48 \mathrm{~m}$. , and $18 \mathrm{~h} .23 \mathrm{~m}$. at the beginning, middle and end of the month, and is not very well placed for observation. Mars and Jupiter are too near the sun for favourable observation. Saturn can be seen late at night or in the early morning hours; at the end of September the planet rises at $22 \mathrm{~h}$. The autumn equinox commences on Sept. 23d. 04h.

\section{Announcements}

Mr. C. T. Gimingham has been promoted to the post of director of the Plant Pathology Laboratory of the Ministry of Agriculture and Fisheries at Harpenden, to succeed Mr. J. C. F. Fryer, who has been appointed secretary to the Agricultural Research Council.

ThE Council of the Institution of Electrical Engineers has decided to continue for the present session the scheme for the admission of non-members of the Institution to any technical meeting of the Institution. Anyone who considers that his technical experience and educational attainments do not suffice to admit him to any form of Institution membership, but who nevertheless wishes to attend meetings of the Institution, can obtain from the secretary an application form, on the completion of which and on payment of a fee of $10 \mathrm{~s}$. to cover administrative costs, he will receive notices of meetings and an invitation card which will serve as'a title of admission.

Dr. G. LAPAGE writes: "May I correct an error in my abstract, entitled 'A Flatworm Parasite of Freshwater 'Trout', of the paper by J. B. Duguid and E. M. Sheppard, printed in Nature of Aug. 5 (p. 185). My abstract implied that Duguid and Sheppard concluded from material sent to them by Dr. Peterson, of Yell, that Diphyllobothrium latum is endemic in freshwater trout in the Shetlands. What these authors actually say is that 'from material kindly sent to us by Dr. Peterson of Yell, we gather that a species of Diphyllobothrium is endemic among freshwater trout in certain of the Shetland Islands'. This is, of course, very different from the statement which I attributed to them and would refer, presumably, to the larval stages". 